\title{
Pengaruh Citra Merek Terhadap Keputusan Pembelian Helm Merek KYT di Kota Surabaya
}

\author{
(The Influence of Brand Image on Purchase Decision of KYT Helmet)
}

Oleh:

\author{
M. Ivan Efendi'), M. Richowanto ${ }^{2)}$, Dwi Ari Lestari ${ }^{3)}$, Siti Ning Farida ${ }^{4)}$ \\ Universitas Pembangunan Nasional "Veteran" Jawa Timur1),2),3),4) \\ zainivanz135@gmail.com¹); richowanto2@gmail.com²); dwiarilestari953@gmail.com³); \\ siti_farida.adbis@upnjatim.ac.id4)
}

\begin{abstract}
ABSTRAK
Penelitian ini bertujuan untuk mengetahui pengaruh Brand Image terhadap keputusan pembelian helm merek KYT di Kota Surabaya. Metode penelitian yang digunakan adalah metode penelitian kuantitatif. Populasi pada penelitian ini adalah seluruh konsumen atau pengguna produk helm merk KYT yang ada di Kota Surabaya. Jumlah sampel yang digunakan adalah sebanyak 100 responden dengan menggunakan metode purposive sampling. Metode pengujian data yang digunakan yaitu uji validitas, uji realibilitas, uji asumsi klasik, uji t, uji $F$, dan analisis regresi linier berganda. Perhitungan data menggunakan software SPSS 23. Berdasarkan hasil penelitian dapat diketahui bahwa citra perusahaan dan citra produk memiliki pengaruh positif dan signifikan terhadap keputusan pembelian helm merek KYT di Kota Surabaya. Sedangkan citra konsumen tidak memiliki pengaruh positif dan signifikan terhadap keputusan pembelian helm merek KYT di Kota Surabaya. Citra produk menjadi variabel yang berpengaruh paling dominan terhadap keputusan pembelian helm merek KYT di Kota Surabaya.
\end{abstract}

Kata kunci:

Citra Merek; Citra Perusahaan; Citra Konsumen; Citra Produk; Keputusan Pembelian

\begin{abstract}
This study aims to determine the effect of Brand Image on purchasing decisions for KYT helmets in Surabaya. The research method used is quantitative research methods. The population in this study were all consumers or users of KYT helmet products in Surabaya. The number of samples used was 100 respondents using purposive sampling method. The data testing method used is validity test, reliability test, classical assumption test, $t$ test, $F$ test, and multiple linear regression analysis. Calculation of data using SPSS 23 software. Based on the results of the study, it can be seen that company image and product image have a positive and significant effect on the purchasing decision of KYT helmet brands in Surabaya. Meanwhile, consumer image does not have a positive and significant effect on the decision
\end{abstract}


to purchase KYT helmet brands in Surabaya. Product image is the variable that has the most dominant influence on the purchasing decision of KYT helmet in Surabaya.

\section{Keywords:}

Brand Image; Company Image; Consumer Image; Product Image; Purchase Decision

\section{PENDAHULUAN}

Era globalisasi saat ini menyebabkan teknologi informasi dan komunikasi berkembang pesat dan memberikan tantangan tersendiri pada persaingan dunia bisnis. Setiap perusahaan harus dapat menciptakan brand image (citra merek) yang lebih baik dari para pesaingnya agar produknya dapat melekat di benak konsumen dan mampu mempengaruhi konsumen dalam melakukan keputusan pembelian produknya. Salah satunya yaitu pada produk helm. Fenomena tersebut dapat dilihat dari kondisi persaingan saat ini yang terjadi pada produk helm, terlebih dengan dikeluarkannya kebijakan pemerintah melalui UU No.22 tahun 2009 pasal 57 ayat 2 yang isinya yaitu mewajibkan pengendara roda 2 mengenakan helm dengan standar SNI. Keanekaragaman produk helm yang ada di pasaran saat ini membuat konsumen melakukan identifikasi dalam pengambilan keputusan saat memilih merek yang dianggap paling memenuhi kriteria konsumen.

Mengacu pada data dari situs www.topbrand-award.com pada tahun 2020, dapat disimpulkan bahwa helm merek KYT memiliki citra merek yang kuat menurut para konsumen di Indonesia. Dengan besaran persentase index 25,9 persen, KYT menduduki peringkat 1 dan menjadi top brand kategori helm dan diikuti oleh INK (18,7\%) dan GM (7,5\%) pada posisi 2 dan 3. Kondisi ini menunjukkan bahwa kebutuhan dan kepekaan konsumen terhadap helm yang aman, canggih dan berkualitas tersebut sangat tinggi. KYT dinilai memiliki fitur keamanan dan kualitas yang sangat baik oleh para konsumen. Namun, besaran persentase indeks ini mengalami penurunan dibandingkan tahun sebelumnya. Pada tahun 2019, KYT memiliki besaran persentasi indeks 30,3\%, diikuti oleh KYT sebesar 19,6\%. Walaupun kedua merek ini mengalami penurunan indeks, namun KYT mengalami penurunan yang cukup signifikan yaitu sebesar 4,4\%, sedangkan INK cukup berhasil menjaga besaran persentase indeksnya dengan hanya mengalami penurunan sebesar $0,9 \%$.

Fenomena penurunan persentase indeks ini dapat mengindikasikan bahwa terdapat permasalahan pada citra merek dari KYT yang dapat mempengaruhi keputusan konsumen untuk membeli produk dari KYT. Permasalahan ini dianggap hal yang penting karena dapat dialami oleh berbagai organisasi dan telah mendasari berbagai penelitian (Sulistyawati, 2011; Saputra, 2017).

Keputusan pembelian adalah tahapan dalam proses pengambilan keputusan konsumen dimana konsumen melakukan pembelian suatu produk barang atau jasa. Keputusan pembelian merupakan tindakan yang dilakukan oleh konsumen karena adanya dorongan atau motif yang dirasakan sehingga konsumen yakin dan memutuskan untuk membeli suatu produk yang dibutuhkannya (Fure, Lapian, dan Taroreh, 2015; Supangkat dan Supriyatin, 
2017). Keputusan pembelian konsumen terbentuk setelah melalui beberapa proses yaitu tahap pengenalan kebutuhan, pencarian informasi, evaluasi alternatif, keputusan pembelian, dan perilaku pascapembelian (Achmadi dan Hidayat, 2018). Keputusan pembelian konsumen dipengaruhi oleh banyak faktor seperti kualitas produk (Putra, Arifin, dan Sunarti, 2017), harga (Rahmadani dan Ananda, 2018), promosi (Njoto dan Sienatra, 2018) serta citra merek (Wulandari dan Iskandar, 2018).

Citra merek adalah suatu kesan atau gambaran yang ditimbulkan oleh suatu merek pada benak pelanggan (Musay, 2013). Citra merek dapat membantu konsumen untuk mengidentifikasi suatu dan membedakannya dengan produk dari pesaing yang sejenis. Konsumen menganggap citra merek merek dapat mencerminkan gambaran suatu produk. Apabila gambaran sebuah merek dibenak konsumen baik, maka konsumen akan dengan mudah menerima produk tersebut di pasar (Prasastiningtyas, 2016). Terdapat 3 komponen yang membentuk sebuah citra merek, komponen tersebut adalah Citra Perusahaan, Citra Konsumen, dan Citra Produk (Simamora, 2011). Citra merek berpengaruh sikap dan keyakinan konsumen kepada suatu merek (Nurhayati, 2017). Keyakinan konsumen pada suatu produk akan membentuk persepsi terhadap citra merek, sehingga dapat meningkatkan citra merek / brand image dan menjadikannya sebagai salah satu aspek penting untuk mempengaruhi keputusan pembelian konsumen (Huda dan Nugroho, 2020). Untuk itu, produsen harus menonjolkan citra merek melalui komunikasi dan kontak merek yang ada (Laheba, Tumbuan, dan Soepeno, 2015).

Dari beberapa penjabaran sebelumnya, dapat diketahui bahwa baik tidaknya citra merek memberikan dampak terhadap keputusan pembelian konsumen. Hal ini berarti perusahaan perlu memahami dengan baik perilaku pembelian dari konsumen untuk dapat membentuk citra merek yang sesuai dengan konsumen yang dituju dan berhasil memenangkan persaingan. Beberapa temuan penelitian menunjukkan bahwa citra merek memiliki pengaruh terhadap keputusan konsumen dalam membeli suatu produk (Kurniawan, Arifin, dan Fanani, 2018; Prasetya, Yulianto, dan Sunarti, 2018). Oleh karena itu, apabila suatu produk memiliki citra merek yang baik dan terkenal, merek tersebut akan tertanam pada benak konsumen yang pada akhirnya akan dipertimbangkan konsumen untuk membeli produk merek tersebut.

Pengaruh citra merek terhadap keputusan pembelian helm merek KYT dapat diangkat menjadi penelitian yang menarik, karena helm merupakan suatu produk penting bagi masyarakat Indonesia, khususnya masyarakat Kota Surabaya yang memiliki mobilitas tinggi dan pengguna sepeda motor yang besar. Masyarakat Kota Surabaya tentunya memiliki pertimbangan-pertimbangan dalam mengambil keputusan untuk membeli suatu merek helm karena helm merupakan perlengkapan perlindungan yang penting Ketika mengendarai sepeda motor. Pada penelitian ini peneliti mengangkat citra merek sebagai faktor yang mempengaruhi keputusan pembelian karena masih sedikit penelitian mengenai pengaruh citra merek produk helm pada keputusan pembelian konsumen. Dengan beberapa hasil temuan penelitian yang ada, maka dirasa masih diperlukan penelitian lain untuk mendapatkan temuan baru pada topik pengaruh citra merek terhadap 
keputusan pembelian, terutama pada produk helm.

\section{METODE PENELITIAN}

Penelitian ini dilaksanakan dengan menyebarkan angket / kuesioner kepada 100 responden yang menjadi bagian dari penelitian yaitu konsumen yang pernah membeli dan menggunakan helm merek KYT di Kota Surabaya. Angket / kuesioner disebar melalui media sosial dalam bentuk google form. Metode pengambilan sampel yang dilakukan pada penelitian ini adalah non probability sampling, artinya semua anggota populasi belum tentu memiliki kesempatan untuk menjadi sampel. Sementara itu penentuan sampel yang digunakan dalam penelitian menggunakan teknik purposive sampling (Sugiyono,2016:85) yaitu teknik pengambilan sampel sumber data dengan pertimbangan tertentu dimana pertimbangan dalam penelitian ini antara lain konsumen yang pernah membeli dan menggunakan helm merek KYT serta berdomisili di Kota Surabaya.

Operasional variabel untuk masingmasing variabel diukur dengan menggunakan indikator yang berbeda seperti yang tersaji pada tabel 1 .

Tabel 1. Operasional Variabel

\begin{tabular}{|c|c|c|}
\hline No. & Variabel & Indikator \\
\hline 1 & $\begin{array}{l}\text { Citra Perusahaan yaitu kumpulan dari asosiasi yang } \\
\text { dipersepsikan oleh konsumen pada perusahaan yang } \\
\text { membuat suatu produk barang atau jasa (Simamora, } 2011\end{array}$ & $\begin{array}{l}\text { Jaringan Penjualan } \\
\text { Inovasi Baru } \\
\text { Popularitas Perusahaan }\end{array}$ \\
\hline 2 & $\begin{array}{l}\text { Citra Konsumen yaitu kumpulan dari asosiasi yang } \\
\text { dipersepsikan oleh konsumen kepada pemakai yang } \\
\text { menggunakan suatu produk barang atau jasa (Simamora, } \\
\text { 2011). }\end{array}$ & $\begin{array}{l}\text { Tampil Gaya } \\
\text { Percaya Diri } \\
\text { Mengikuti Tren }\end{array}$ \\
\hline 3 & $\begin{array}{l}\text { Citra Produk yaitu kumpulan asosasi yang dipersepsikan } \\
\text { oleh konsumen kepada suatu produk (Simamora, 2011). }\end{array}$ & $\begin{array}{l}\text { Mudah Dikenali } \\
\text { Tampilan Produk } \\
\text { Fitur Produk } \\
\text { Varian Produk }\end{array}$ \\
\hline 4 & $\begin{array}{l}\text { Keputusan Pembelian adalah proses konsumen dalam } \\
\text { mengenali masalahnya, mencari informasi mengenai } \\
\text { produk atau merek dan melakukan evaluasi terhadap } \\
\text { masing-masing alternatif tersebut yang dapat } \\
\text { memecahkan masalahnya, yang kemudian mengarahkan } \\
\text { konsumen kepada keputusan pembelian (Tjiptono, 2014) }\end{array}$ & $\begin{array}{l}\text { Identifikasi Kebutuhan } \\
\text { Pencarian Informasi } \\
\text { Evaluasi Alternatif } \\
\text { Keputusan Pembelian } \\
\text { Perilaku Pasca } \\
\text { Pembelian }\end{array}$ \\
\hline
\end{tabular}
Sumber: Data penelitian diolah, 2020

Desain penelitian pada gambar 1 dibawah ini menunjukkan pengaruh antar variabel yang diteliti dalam penelitian ini yaitu Citra Perusahaan (X1), Citra Konsumen (X2), Citra Produk (X3), dan Keputusan Pembelian (Y).
Untuk mempertahankan citra merek perusahaan haruslah memperhatikan citra perusahaan, citra konsumen, serta citra produknya karena apabila ketiga citra tersebut baik di mata konsumen, maka akan memberikan rasa yakin dan percaya 
kepada produk yang dikeluarkan oleh perusahaan sehingga konsumen memutuskan untuk melakukan pembelian produk perusahaan.

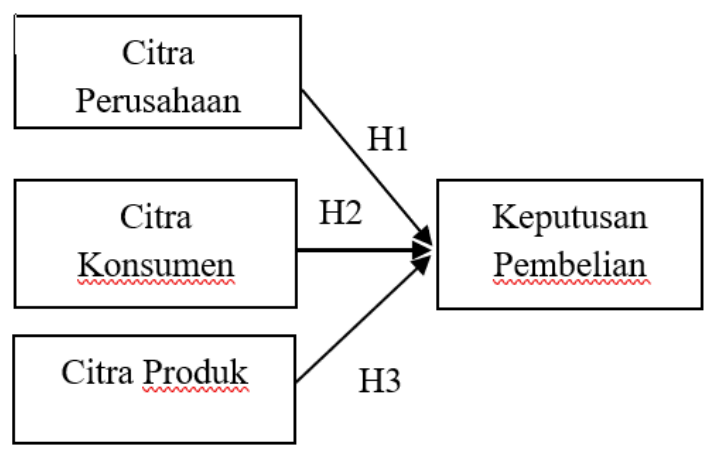

Gambar 1. Desain Penelitian

Metode penelitian yang digunakan dalam penelitian ini adalah metode penelitian kuantitatif yang meliputi uji validitas, uji realibilitas, uji asumsi klasik (uji normalitas, uji multikolinearitas, uji heterokedastisitas), analisis regresi linier berganda ,analisis uji $t$, uji $F$, dan koefisien determinasi.

\section{HASIL PENELITIAN}

Berdasarkan hasil dari kuesioner yang telah disebarkan sebelumnya, diketahui bahwa responden penelitian ini terdiri dari $56 \%$ laki-laki dan $44 \%$ perempuan. Rentang usia responden yang terbanyak yaitu usia 21-25 tahun sebesar 70\%. Jenis pekerjaan responden sebagian besar merupakan pelajar/mahasiswa sebesar $74 \%$ dan penghasilan mayoritas responden dalam penelitian ini yaitu sebesar $\leq$ Rp.2.000.000 dengan persentase sebesar $70 \%$.

Penelitian ini menggunakan instrumen kuesioner sehingga perlu dilakukan uji instrumen yaitu uji validitas dan uji reliabilitas. Variabel Citra Perusahaan terdiri dari 3 (tiga) item pertanyaan kuesioner. Variabel Citra
Konsumen terdiri dari 3 (tiga) item pernyataan kuesioner. Variabel Citra Produk terdiri dari 4 (empat) item pernyataan kuesioner. Variabel Keputusan Pembelian terdiri dari 6 (enam) item pernyataan kuesioner. Seluruh item variabel bebas dan terikat dalam penelitian ini memiliki nilai $R$ hitung $\geq R$ tabel $(0,1966)$ sehingga dinyatakan valid. Sedangkan untuk uji realibilitas dapat diketahui bahwa seluruh butir pernyataan menghasilkan nilai Cronbach Alpha yang nilainya lebih tinggi dari 0,6 sehingga semua variabel dalam penelitian ini, yaitu citra perusahaan, citra konsumen, citra produk, dan keputusan pembelian dinyatakan realibel dan kuesioner yang digunakan dalam penelitian sudah representatif, yaitu dapat dipercaya dan diandalkan.

Data uji validitas dan uji realibilitas dapat dilihat pada tabel 2 dan tabel 3.

Tabel 2. Uji Validitas

\begin{tabular}{lcc}
\hline \multicolumn{1}{c}{ Variabel } & Item & R hitung \\
\hline Citra Perusahaan & X.1.1 & 0,770 \\
& X.1.2 & 0,809 \\
& X.1.3 & 0,799 \\
\hline Citra Konsumen & X.2.1 & 0,884 \\
& X.2.2 & 0,891 \\
& X.2.3 & 0,869 \\
\hline Citra Produk & X.3.1 & 0,671 \\
& X.3.2 & 0,709 \\
& X.3.3 & 0,738 \\
Keputusan & X.3.4 & 0,767 \\
\hline Pembelian & Y.1 & 0,584 \\
& Y.2 & 0,662 \\
& Y.3 & 0,825 \\
& Y.4 & 0,694 \\
& Y.5 & 0,801 \\
& Y.6 & 0,729 \\
\hline
\end{tabular}

Sumber: Data diolah, 2020 
Tabel 3. Uji Realibilitas

\begin{tabular}{lcc}
\hline \multirow{2}{*}{ Variabel } & \multicolumn{2}{c}{ Realibilitas } \\
\cline { 2 - 3 } & $\begin{array}{c}\text { Cronbach's } \\
\text { Alpha }\end{array}$ & Kritis \\
\hline Citra Perusahaan (X1) & 0,701 & 0,6 \\
Citra Konsumen (X2) & 0,856 & 0,6 \\
Citra Produk (X3) & 0,689 & 0,6 \\
Keputusan Pembelian (Y) & 0,813 & 0,6 \\
\hline
\end{tabular}

Sumber: Data diolah, 2020

Persyaratan untuk analisis regresi linier berganda telah terpenuhi. Uji normalitas menunjukkan nilai signifikan > 0,05 yaitu 0,2 sehingga dapat dinyatakan bahwa data terdistribusi secara normal. Uji multikolinieritas menunjukkan nilai VIF pada ketiga variabel bebas $<10$, yaitu 1,806 untuk variabel citra perusahaan, 1,636 untuk variabel citra konsumen, dan 1,762 untuk variabel citra produk, sehingga dapat disimpulkan bahwa data dalam penelitian ini tidak terdapat multikolinearitas. Uji heteroskedastisitas dengan scatter plot menunjukkan bahwa persebaran data tidak membentuk pola seperti bergelombang, menyebar, dan menyempit, serta titik tersebar rata di atas dan di bawah nilai nol pada sumbu Y. Berdasarkan pada keadaan tersebut, dapat dinyatakan bahwa data terdistribusi secara normal dan tidak terjadi gejala heteroskedastisitas.

Kelayakan model dapat dilihat dari nilai koefisien determinasi sebesar 0,605 dan adjusted $R$ square sebesar 0,593 seperti yang tersaji pada tabel 4 .

Tabel 4. Uji Koefisien Determinasi

\begin{tabular}{ccccc}
\hline Model & R & $\begin{array}{c}\text { R } \\
\text { Square }\end{array}$ & $\begin{array}{c}\text { Adj. R } \\
\text { Square }\end{array}$ & $\begin{array}{c}\text { Etror of } \\
\text { The } \\
\text { Estimate }\end{array}$ \\
\hline 1 & 0,778 & 0,605 & 0,593 & 2,34951 \\
\hline
\end{tabular}

Sumber: Data diolah, 2020
Uji kelayakan model dapat disimpulkan layak dimana hasil pengujian mendapatkan nilai Sig. F sebesar 0,000 atau dibawah taraf uji penelitian sehingga Ho ditolak. Hasil analisis untuk uji-F tersaji pada tabel 5 .

Tabel 5. Uji F

Model $\begin{gathered}\text { Sum of } \\ \text { Squares }\end{gathered}$ df $\begin{gathered}\text { Mean } \\ \text { Square }\end{gathered}$ F Sig.

Regression 812,420 3270,80749,057 0,000

Residual 529,940 $96 \quad 5,520$

Total 1342,360 99

Sumber: Data diolah, 2020

Hasil perhitungan dengan menggunakan program SPSS versi 23, dapat diketahui nilai koefisien determinan sebesar 0,605. Besaran angka koefisien determinasi ( $\mathrm{R}$ Square) sama dengan $60,5 \%$. Angka tersebut memiliki arti yaitu variabel citra perusahaan (X1), citra konsumen (X2), citra produk (X3) mempengaruhi keputusan pembelian $(\mathrm{Y})$ sebesar $60,5 \%$, sisanya 39,5\% dipengaruhi oleh variabel yang tidak diteliti dalam penelitian ini.

Pengujian hipotesis dilakukan dengan berdasarkan koefisien regresi dan nilai probabilitas. Berdasarkan tabel 6, dapat diperoleh persamaan regresi sebagai berikut:

$Y=-0.478+0,369 X 1+0,123 X 2+1,120 X 3$

Variabel Citra Perusahaan (X1) memiliki nilai $\mathrm{t}$ hitung sebesar 2,014 > t tabel sebesar 1,984 dengan tingkat signifikansi $0,047<0,05$ serta koefisien variabel 0,369 yang artinya jika Citra Perusahaan mengalami kenaikan, maka Keputusan Pembelian konsumen akan mengalami kenaikan sebesar 0,369 atau $36,9 \%$. Hal ini menunjukkan adanya pengaruh positif dan signifikan secara parsial antara variabel bebas (X1) dengan 
variabel terikat (Y) sehingga dapat disimpulkan bahwa H1 diterima. Variabel Citra Konsumen (X2) memiliki nilai $t$ hitung sebesar 0,959< $\mathrm{t}$ tabel sebesar 1,984 dengan tingkat signifikansi 0,340>0,05 serta koefisien variabel sebesar 0,123 artinya jika Citra Konsumen mengalami kenaikan, maka Keputusan Pembelian konsumen akan mengalami peningkatan sebesar 0,123 atau $12,3 \%$. Hal ini menunjukkan variabel bebas (X2) berpengaruh positif namun tidak signifikan terhadap variabel terikat $(Y)$ sehingga dapat disimpulkan bahwa $\mathrm{H} 2$ ditolak. Variabel Citra Produk (X3) memiliki nilai $\mathrm{t}$ hitung sebesar 7,165 > t tabel sebesar 1,984 dengan tingkat signifikansi $0,000<0,05$ serta koefisien variabel sebesar 1,120 artinya jika Citra Produk mengalami kenaikan, maka Keputusan Pembelian konsumen akan mengalami peningkatan sebesar 1,120 atau $112,0 \%$. Hal ini menunjukkan adanya pengaruh positif dan signifikan secara parsial antara variabel bebas (X3) dengan variabel terikat $(Y)$ sehingga dapat disimpulkan bahwa $\mathrm{H} 3$ diterima.

Tabel 6. Analisis Regresi Linier Berganda

\begin{tabular}{lccccc}
\hline \multirow{2}{*}{ Model } & \multicolumn{2}{c}{$\begin{array}{c}\text { Unstandardized } \\
\text { Coefficients }\end{array}$} & $\begin{array}{c}\text { Standardized } \\
\text { Coefficients }\end{array}$ & $\mathrm{t}$ & Sig. \\
\cline { 2 - 4 } & $\mathrm{B}$ & Std. Error & Beta & & $-0,238$ \\
\hline (Constant) & $-0,478$ & 2,007 & & 0,812 \\
Citra Perusahaan & 0,369 & 0,183 & 0,174 & 2,014 & 0,047 \\
Citra Konsumen & 0,123 & 0,128 & 0,079 & 0,959 & 0,340 \\
Citra Produk & 1,120 & 0,156 & 0,610 & 7,165 & 0,000 \\
\hline
\end{tabular}

Sumber: Data diolah, 2020

\section{PEMBAHASAN}

Penelitian ini menghasilkan temuan bahwa Citra Konsumen berpengaruh positif namun tidak signifikan terhadap Keputusan Pembelian. Citra Perusahaan dan Citra Produk masing-masing memiliki pengaruh positif dan signifikan terhadap Keputusan Pembelian dimana Citra Produk berpengaruh paling dominan dalam mempengaruhi Keputusan Pembelian konsumen.

\section{Pengaruh Citra Perusahaan Terhadap Keputusan Pembelian}

Citra perusahaan berpengaruh positif dan signifikan terhadap keputusan pembelian. Semakin baik citra perusahaan maka semakin tinggi keputusan konsumen membeli produk helm merek KYT di Kota Surabaya. Hal ini menunjukkan bahwa PT. Tarakusuma Indah selaku produsen helm merek KYT dikenal oleh konsumen di Kota Surabaya sebagai produsen helm berkualitas dengan berbagai inovasi baru dan memiliki jaringan penjualan produk yang luas.

Hasil dari penelitian ini didukung oleh penelitian Musay (2013) yang menjelaskan bahwa citra perusahaan terbukti memiliki pengaruh yang signifikan terhadap keputusan pembelian. Penelitian lain dari Prasetya, Yulianto, dan Sunarti (2018) menjelaskan bahwa konsumen melakukan keputusan pembelian dengan melihat 
popularitas perusahaan, kredibilitas perusahaan, serta jaringan perusahaan.

\section{Pengaruh Citra Konsumen Terhadap Keputusan Pembelian}

Citra konsumen tidak berpengaruh positif dan signifikan terhadap keputusan pembelian. Hal ini menjelaskan bahwa citra konsumen produk helm merek KYT tidak terlalu diperhatikan oleh konsumen dalam melakukan keputusan pembelian.

Hasil dari penelitian ini didukung oleh penelitian Musay (2013) yang menjelaskan bahwa citra konsumen tidak terbukti memiliki pengaruh yang signifikan terhadap keputusan pembelian. Pada penelitian tersebut dijelaskan bahwa dengan membeli atau mengkonsumsi produk tertentu dianggap tidak dapat mencerminkan status sosial seseorang di dalam masyarakat.

\section{Pengaruh Citra Poduk Terhadap Keputusan Pembelian}

Citra produk berpengaruh positif dan signifikan terhadap keputusan pembelian. Citra produk yang baik akan meningkatkan keputusan konsumen membeli produk helm merek KYT di Kota Surabaya. Hal ini menunjukkan bahwa konsumen di Kota Surabaya menganggap helm merek KYT memiliki bentuk / tampilan yang menarik sehingga mudah dikenali. Selain itu helm merek KYT juga dianggap memiliki varian model yang bervariasi dan dilengkapi standar keamanan produk yang bermutu sehingga menimbulkan citra produk yang baik.

Hasil dari penelitian ini didukung oleh penelitian Musay (2013) yang menjelaskan bahwa citra produk terbukti memiliki pengaruh yang signifikan terhadap keputusan pembelian. Menurut Schiffman dan Kanuk (2008:174) citra produk yang dirasa menyenangkan mempunyai peluang yang jauh lebih baik untuk dibeli dari pada produk yang mempunyai citra tidak menyenangkan atau netral. Penelitian lain dari Prasetya, Yulianto, dan Sunarti (2018) menyatakan bahwa konsumen cenderung melakukan keputusan pembelian dengan melihat atribut, manfaat dan jaminan.

\section{Citra Produk Berpengaruh Paling Dominan Terhadap Keputusan Pembelian Konsumen}

Variabel yang memiliki pengaruh paling dominan terhadap keputusan pembelian produk helm merek KYT di Kota Surabaya adalah variabel citra produk. Penelitian ini mendukung hasil penelitian sebelumnya dari Musay (2013) yang menjelaskan bahwa citra produk merupakan variabel yang memiliki pengaruh paling dominan terhadap keputusan pembelian dibandingkan dua variabel lainnya. Musay (2013) menjelaskan bahwa konsumen akan mempertimbangkan citra dari produk itu terlebih dahulu seperti atribut yang terdapat dalam produk, manfaat yang diberikan oleh produk dan jaminan produk ketika memutuskan membeli suatu merek atau produk.

\section{KESIMPULAN}

Penelitian ini menghasilkan kesimpulan bahwa Citra Konsumen berpengaruh positif namun tidak signifikan terhadap Keputusan Pembelian. Citra Perusahaan dan Citra Produk berpengaruh positif dan signifikan terhadap Keputusan Pembelian dengan Citra Produk berpengaruh paling dominan dalam mempengaruhi Keputusan Pembelian helm merek KYT pada konsumen di Kota Surabaya. 
PT. Tarakusuma Indah selaku produsen helm merek KYT sebaiknya mempertahankan citra perusahaan dan produk yang ada saat ini, serta meningkatkan citra konsumen dengan cara memahami karakteristik dan keinginan konsumen agar kedepannya helm merek KYT dapat lebih mencerminkan citra dari konsumennya sehingga mempengaruhi keputusan pembelian konsumen.

\section{DAFTAR PUSTAKA}

Achmadi, R.N., \& Hidayat, A.M. (2018). Pengaruh Brand Image Terhadap Keputusan Pembelian Produk Honda Beat di Kota Bandung tahun 2017. e-Proceeding of Applied Science Universitas Telkom, 4(1), 20-33.

Fure, F., Joyce Lapian, \& Taroreh R. (2015). Pengaruh Brand Image, Kualitas Produk dan Harga Terhadap Keputusan Pembelian Konsumen Di J.Co Manado. Jurnal EMBA Universitas Sam Ratulangi Manado, 3(1), 367-377.

Huda, O.K., \& Nugroho, A.T. (2020). Pengaruh Word of Mouth Dan Citra Merek Terhadap Loyalitas Pelanggan Smartphone Oppo Dimediasi Kepercayaan Merek. Jurnal Pengembangan Wiraswasta STIE IPWIJA, 2(22), 141-150. http://dx.doi.org/10.33370/jpw.v22 i02.436

Kurniawan, F., Zainul Arifin, \& Fanani, D. (2018). Pengaruh Citra Merek Terhadap Keputusan Pembelian (Survei kepada para siswa SMAN 15 Surabaya kelas XII yang menggunakan Laptop ber Merek ASUS). Jurnal Administrasi Bisnis, 56(1), 75-81.

Laheba, Y.A., Willem J.F. Alfa Tumbuan, dan Soepeno, D. (2015). Pengaruh
Citra Merek, Fitur dan Harga Terhadap Keputusan Pembelian Handphone Samsung (Studi Pada Mahasiswa FEB Unsrat Manado). Jurnal EMBA Universitas Sam Ratulangi Manado, 3(3), 99-108.

Musay, F.P. (2013). Pengaruh Brand Image Terhadap Keputusan Pembelian (Survey pada Konsumen KFC Kawi Malang). Jurnal Administrasi Bisnis, 3(2).

http:/ / administrasibisnis.studentjou rnal.ub.ac.id/index.php/jab/article /view/141

Njoto, D.P., \& Sienatra, K.B. (2018). Pengaruh Promosi Terhadap Keputusan Pembelian Konsumen Wenak Tok. PERFORMA: Jurnal Manajemen dan Start-Up Bisnis, 3(5), 613-618.

Nurhayati, S. (2017). Pengaruh Citra Merek, Harga dan Promosi Terhadap Keputusan Pembelian Handphone Samsung Di Yogyakarta. Jurnal Bisnis, Manajemen, dan Akuntansi, 4(2), 60-69. http://jurnal.amaypk.ac.id/index.p hp/jbma/article/view/66.

Prasastiningtyas, T.R., \& Djawoto. (2016). Pengaruh Citra Merek, Kualitas Produk, dan Harga Terhadap Keputusan Pembelian Kartu Seluler. Jurnal Ilmu dan Riset Manajemen, 5(7), 1-15.

Prasetya, E.G., Edy Yulianto, \& Sunarti. (2018). Pengaruh Brand Image Terhadap Keputusan Pembelian (Survei Pada mahasiswa Fakultas Ilmu Administrasi Bisnis Progam Studi Administrasi Bisnis angkatan 2014 konsumen Air Mineral Aqua ). Jurnal Administrasi Bisnis, 62(2), 214221.

http://administrasibisnis.studentjou 
rnal.ub.ac.id/index.php/jab/article /view/2692

Putra, G.P., Zainul Arifin, dan Sunarti. (2017). Pengaruh Kualitas Produk terhadap Keputusan Pembelian dan Dampaknya Terhadap Kepuasan Konsumen (Survey pada Mahasiswa Administrasi Bisnis Fakultas Ilmu Administrasi angkatan 2013 dan 2014 Universitas Brawijaya yang Melakukan Pembelian Paket Data Kampus). Jurnal Administrasi Bisnis, 48(1), 124-131.

Rahmadani, R., \& Ananda, F. (2018). Analisis Pengaruh Harga Terhadap Keputusan Pembelian di Online Shop Tokopedia. https://doi.org/10.31227/osf.io/as9 wc

Saputra, A.W. (2017). Pengaruh Citra Merek dan Kualitas Produk Terhadap Keputusan Pembelian Mobil Merek Isuzu Panther (Studi Kasus pada Konsumen PT. Astra Isuzu International Semarang). Diponegoro University Journal Of Social And Politic, Business Administration.

Schiffman, L., \& Kanuk, L.L. (2008). Consumer Behaviour (edisi ketujuh). Jakarta:PT Indeks.
Simamora, B. (2011). Memenangkan Pasar Dengan Pemasaran Efektif dan Profitabel. Jakarta: PT Gramedia Pustaka Utama.

Sugiyono. (2016). Metode Penelitian Kuantitatif, Kualitatif, dan RED. Bandung: Alfabeta.

Sulistyawati, P. (2011). Analisis Pengaruh Citra Merek dan Kualitas Produk Terhadap Keputusan Pembelian Laptop Merek Acer di Kota Semarang. UNDIP E-journal. http://eprints.undip.ac.id/26500/

Supangkat, A.H., \& Supriyatin. (2017). Pengaruh Citra Merek, Kualitas Produk, Harga Terhadap Keputusan Pembelian Tas di Intako. Jurnal Ilmu dan Riset Manajemen, 6(9), 1-19.

Tjiptono, F. (2014). Pemasaran Jasa - Prinsip, Penerapan, dan Penelitian. Yogyakarta: Andi Offset.

Wulandari, R.D., \& Iskandar, D.A. (2018). Pengaruh Citra Merek dan Kualitas Produk Terhadap Keputusan Pembelian Pada Produk Kosmetik. Jurnal Riset Manajemen dan Bisnis (JRMB) Fakultas Ekonomi UNIAT Vol.3, No.1 Februari 2018, 11 - 18. 